\title{
EFFECT OF SURFACE
}

TREATMENT ON THE

CORROSION RESISTANCE OF

ZIRCALOY-2

APRIL 1961

CONTRACT AT-11-1-GEN-14

BETTIS ATOMIC POWER LABORATORY, PITTSBURGH, PA., OPERATED FOR THE U.S. ATOMIC ENERGY COMMISSION BY WESTINGHOUSE ELECTRIC CORPORATION 


\section{DISCLAIMER}

This report was prepared as an account of work sponsored by an agency of the United States Government. Neither the United States Government nor any agency Thereof, nor any of their employees, makes any warranty, express or implied, or assumes any legal liability or responsibility for the accuracy, completeness, or usefulness of any information, apparatus, product, or process disclosed, or represents that its use would not infringe privately owned rights. Reference herein to any specific commercial product, process, or service by trade name, trademark, manufacturer, or otherwise does not necessarily constitute or imply its endorsement, recommendation, or favoring by the United States Government or any agency thereof. The views and opinions of authors expressed herein do not necessarily state or reflect those of the United States Government or any agency thereof. 


\section{DISCLAIMER}

Portions of this document may be illegible in electronic image products. Images are produced from the best available original document. 
UC-25: Metals, Ceramics, and Materials TID-4500 (16th Edition)

\section{EFFECT OF SURFACE TREATMENT \\ ON THE \\ CORROSION RESISTANCE OF ZIRCALOY-2 \\ D. B. Scott}

April 1961

Contract AT-11-1-GEN-14

Price $\$ .50$

Available from the Office of Technical Services,

Department of Commerce,

Washington 25, D. C.

This document is an interim memorandum prepared primarily for internal reference and does not represent a final expression of the opinion of Westinghouse. When this memorandum is distributed externally, it is with the express understanding that Westinghouse makes no representation as to completeness, accuracy, or usability of information contained therein.

BETTIS ATOMIC POWER LABORATORY, PITTSBURGH, PA., OPERATED FOR THE U. S. ATOMIC ENERGY COMMISSION BY WESTINGHOUSE ELECTRIC CORPORATION 


\section{SPECIAL EXTERNAL DISTRIBUTION}

Manager, Pittsburgh Naval Reactors Operations Office, AEC

Director, Development Division, PNROO

\begin{tabular}{rr} 
& 7 \\
Total & 3 \\
\hline 588
\end{tabular}

\section{LEGAL NOTICE}

This report was prepared as an account of Government sponsored work. Neither the United states, nor the Commission, nor any person acting on behalf of the Commission:

A. Makes any warranty or representation, expressed or implied, with respect to the accuracy, completeness, or usefulness of the information contained in this report, or that the use of any information, apparatus, method, or process disclosed in this report may not infringe privately owned rights; or

B. Assumes any liabilities with respect to the use of, or for damages resulting from the use of any information, apparatus, method, or process disclosed in this report.

As used in the above, "person acting on behalf of the Commission" includes any employe or contractor of the Commission, or employe of such contractor, to the extent that such omployo or oontrastor of the commission, or employe of sush sontractor prepares, dissemi. nates, or provides access to any information pursuant to his employment or contract with the Commission, or his employment with such contractor. 
Page No.

I. INTRODUCTION

II. FXPERTMENTAL PROCEDURE 1

A. Machined Surfaces 1

B. Corrosion Test Preparation 2

III. RESULTS 2

A. Unpickled Machined Coupons 2

B. Pickled Machined Coupons 2

IV. DISCUSSION - 6

A. Unpickled Machined Coupons 6

B. Pickled Machined Coupons 6

V. CONCLUSIONS 9

APPENDIX I: STATISTICAL ANALYSIS 99

A. Method of Analysis 17

B. Conclusions 17

ACKNOWLEDGMENTS 17

REFERENCES 


\begin{abstract}
An experiment was performed to delermine the effects of nonpickling versus pickling to depths of one and two mils on the corrosion resistance of Zircaloy-2 machined by various methods. No significant difference in corrosion rate belween pickled and unpickled Zircaloy-2 was found, provided that properly sharpened and hardened fools were used.
\end{abstract}

\title{
EFFECT OF SURFACE TREATMENT ON THE
}

CORROSION RESISTANCE OF ZIRCALOY-2

\section{D.B.Scott}

\section{INTRODUCTION}

A previous investigation of Goldman (Ref 1) demonstrated that the surface layers of metal on zirconium are distorted by machining operations and that the distorted metal corrodes more rapidly in high temperature water and steam than the base metal. In addition, these surface layers could be removed by bright etching in an aqueous solution of nitric and hydrofluoric acid. Although the distorted surface layers of zirconium and Zircaloy-2 were approximately equal in thickness, the corrosion behavior of the layers was markedly different-since the zirconium surfaces corroded rapidly, whereas the Zircaloy-2 surfaces exlibited good corrosion resistance (Ref 1 ). Later work at Bettis Laboratory (Ref 2)* provided additional qualitative data demonstrating the superior corrosion resistance of properly machined Zircaloy-2 surfaces.

The scope of the experiment reported here is an extension of the earlier investigation and defines the steam and aqueous corrosion resistance

*Alsn, .T.C. Helhling and S. Kass, Bettis Laboratory Personal Communication (1958). of pickled and unpickled Zircaloy-2 as a function of the surface finish provided by various machining processes and tools.

\section{EXPERIMENTAL PROCEDURE}

\section{A. Machined Surfaces}

To obtain samples of different machined surfaces, Zircaloy-2 coupons, $0.1 \times 0.5 \times 1.5$ inches in size, were machined with eight types of machine tools. Strips, previously machined to 0.120 -inch thickness from one section of an atmosphere melted, reactor grade ingot, were used as the source stock. The machine tools used on the coupons were:

1) Shaper

2) Slab Mill

3) Straddle Mill

4) Shell Mill (Facing Mill)

5) End Mill with overlap cut

6) End Mill with non-overlap cut

7) End Mill with edge cut

8) Surface Grinder (wheel)

Coupons were prepared using both sharp and dull cutters with fine, medium, and coarse feeds. 
The surface-ground specimens were exceptions since only a new wheel with fine, medium, and coarse feeds could be used.

For the purpose of this experiment, a sharp tool is defined as one newly sharpened, a dull tool as one ready to be sharpened. In all machining operations with the exception of surface grinding no lubricant was used. Because of the nature of the cutting action, surface grinding required the liberal use of coolant. The machining record is given in Table $I$.

\section{B. Corrosion Test Preparation}

Coupons from each surface treatment were divided into three lots. Lot 1 was degreased by scrubbing with acetone and alcohol; lots 2 and 3 were pickled with an aqueous solution of $\mathrm{HF}$ and $\mathrm{HNO}_{3}$ to remove 1 and 2 mils per surface, respectively. All coupons were corrosion tested in $680^{\circ} \mathrm{F}$ water or $750^{\circ} \mathrm{F}$ steam.

\section{RESULTS}

\section{A. Unpickled Machined Coupons}

The weight gains of the coupons after the first 14 days in $750^{\circ} \mathrm{F}$ steam and 28 days in $680^{\circ} \mathrm{F}$ water are shown in Tables II and III. With the exception of the straddle-milled coupons, the weight gains in both $750^{\circ} \mathrm{F}$ steam and $680^{\circ} \mathrm{F}$ water were normal, and all coupons exhibited black oxide films with white stringers-a normal condition for corrosion-tested, atmosphere-melted Zircaloy-2. One flat surface of the straddle-milled coupons was white, while the other flat surface exhibited a black temper film with stringers (see Figure 1). The white corrosion film, attributed to a defective tool, is discussed later.

The fine, medium, and coarse variations in feed were found to be insignificant in their effects on corrosion resistance, as verified by the Bettis Statistical Engineering staff (Appendix I). Since no changes in corrosion behavior were noted throughout the corrosion tests, the results for the particular tools were averaged regardless of feed and are tabulated in Tables IV and VII for the times in test.

As the tests continued, the effect of the "sharp" and "dull" tools was noticeable on the facemilled coupons (shell mill) after 84 days in $750^{\circ} \mathrm{F}$ steam and 112 days in $680^{\circ} \mathrm{F}$ water. At these times, erratic weight gains (shown in Tables IV and VII) were indicative of poor corrosion resistance for the coupons milled with a dull cutter. The poor corrosion behavior of the one face of the straddle milled coupons (white corrosion film) continued for the duration of the lest. Except for the dull cut face-milled and straddlemilled coupons, all other machined coupons including the surface-ground specimens had slightly lower than normal weight gains and black-gray temper films with stringers throughout the test (140 days in $750^{\circ} \mathrm{F}$ steam and 224 days in $680^{\circ} \mathrm{F}$ water).

\section{B. Pickled Machined Coupons}

The weight gains for the first 14 days in $750^{\circ} \mathrm{F}$ steam and 28 days in $680^{\circ} \mathrm{F}$ water are shown in 'lables 11 ànd ITT. All machined cuujuus, without exception, exhibited shiny black temper films with stringers. No evidence of white corrosion product was noted on the straddle-milled (Figure 2) and slab-inilled coupons.

As with the unplukled coujuins of this expcriment, variations in feed produced insignificant effects for the duration of test. The results are shown in Tables V, VI, VIII and IX. Comparison bar graphs for 84 and 140 days are shown in Figures 3 and 4.

The weight gains in $680^{\circ} \mathrm{F}$ water showed that all pickle trealments gave results within the normal experimental scatter, as shown in the bar graphs for 112 and 196 days in test (Figures 5 and 6). 
TABLE I

MACHINING RECORD ON MACHINING ZIRCALOY-2 CORROSION COUPONS

$\begin{array}{ll}\text { Sharp Tool: } & \begin{array}{l}\text { Fine Feed } \\ \text { Medium Feed } \\ \text { Dull Tool: }\end{array} \\ \begin{array}{l}\text { Coarse Feed } \\ \text { Fine Feed } \\ \text { Medium Feed } \\ \text { Coarse Feed }\end{array}\end{array}$

Slab Mill

\begin{tabular}{ll}
\hline Sharp Tool: & $\begin{array}{l}\text { Fine Feed } \\
\text { Medium Feed } \\
\text { Coarse Feed }\end{array}$ \\
Dull Tool: & $\begin{array}{l}\text { Fine Feed } \\
\text { Medium Feed } \\
\text { Cuarse Feed }\end{array}$
\end{tabular}

Straddle Mill

\begin{tabular}{ll}
\hline Sharp Tool: & $\begin{array}{l}\text { Fine Feed } \\
\text { Medium Feed } \\
\text { Coarse Feed }\end{array}$ \\
Dull Tool: & $\begin{array}{l}\text { Fine Feed } \\
\text { Medium Feed } \\
\text { Coarse Feed }\end{array}$ \\
&
\end{tabular}

\begin{tabular}{ll}
\hline Sharp Tool: & $\begin{array}{l}\text { Fine Feed } \\
\text { Medium Feed }\end{array}$ \\
& $\begin{array}{l}\text { Coarse Feed } \\
\text { Dull Tool: }\end{array}$ \\
& $\begin{array}{l}\text { Fine Feed } \\
\text { Medium Feed } \\
\text { Coarse Feed }\end{array}$
\end{tabular}

End Mill

Overlap Facing

\begin{tabular}{ll}
\hline Sharp Tool: & $\begin{array}{l}\text { Fine Feed } \\
\text { Medium Feed }\end{array}$ \\
& Coarse Feed \\
Dull Tool: & $\begin{array}{l}\text { Fine Feed } \\
\text { Medium Feed } \\
\end{array}$ \\
& Coarse Feed
\end{tabular}

End Mill

$\frac{\text { (No Overlap Facing) }}{\text { Sharp Cutter: }} \begin{aligned} & \text { Fine Feed } \\ & \text { Medium Feed } \\ & \text { Coarse Feed }\end{aligned}$

Dull Cutter: Fine Feed Medium Feed Coarse Feed

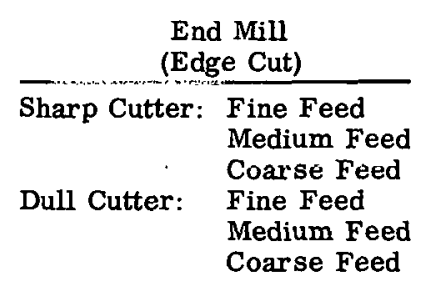

Surface Grinder

\begin{tabular}{ll}
\hline New Wheel: & $\begin{array}{l}\text { Fine Feed } \\
\text { Medlum Feed } \\
\text { Cóarse Feed }\end{array}$
\end{tabular}

\begin{tabular}{|c|c|}
\hline $\begin{array}{c}\text { Feed } \\
\text { (in./stroke) }\end{array}$ & $\begin{array}{l}\text { Speed } \\
\text { (strokes/min) }\end{array}$ \\
\hline 0.004 & 12 \\
\hline 0.010 & 12 \\
\hline 0.015 & 12 \\
\hline 0.004 & 12 \\
\hline 0.010 & 12 \\
\hline 0.020 & 15 \\
\hline
\end{tabular}

\begin{tabular}{c} 
Speed(rpm) \\
\hline 33 \\
33 \\
25 \\
33 \\
25 \\
25
\end{tabular}

\begin{tabular}{l} 
Diameter of Cutter \\
\hline 6 in. $x 1$ in. (22 teeth) \\
6 in. $x 1$ in. (22 teeth) \\
6 in. $x 1$ in. (22 teeth) \\
6 in. $x 1$ in. (22 teeth) \\
6 in. $x 1$ in. (22 teeth) \\
6 in. $x 1$ in. (22 teeth)
\end{tabular}

\begin{tabular}{c} 
Speed(rpm) \\
\hline 18 \\
18 \\
18 \\
18 \\
18 \\
18
\end{tabular}

(in. $/ \mathrm{min}$ )

$\begin{array}{rr} & 5 / 8 \\ 1 & 1 / 4 \\ 6 & 1 / 8 \\ 5 / 8 \\ 1 & 1 / 4 \\ 6 & 1 / 8\end{array}$

\begin{tabular}{c} 
Speed(rpm) \\
\hline 43 \\
43 \\
43 \\
56 \\
43 \\
25
\end{tabular}

Feed

(in./min)

$7 / 8$

$23 / 8$

$31 / 4$

$5 / 8$

$13 / 4$

$31 / 4$

\begin{tabular}{c} 
Speed(rpm) \\
\hline 168 \\
168 \\
168 \\
225 \\
168 \\
168
\end{tabular}

Feed

(in. $/ \mathrm{min}$ )

5/16
$7 / 16$
$7 / 8$
$5 / 16$
$7 / 8$
$11 / 4$

\begin{tabular}{c} 
Speed(rpm) \\
\hline 100 \\
76 \\
76 \\
100 \\
100 \\
76
\end{tabular}

Feed

(in. $/ \mathrm{min}$ )

$11 / 4$

1 $3 / 4$

$23 / 8$

$7 / 8$

$13 / 4$

$13 / 4$

Feed

(in./min)

0.001

0. Uuib

0.003

Diameter of Shell Mill

3 in. (12 flute)
3 in. (12 flute)
3 in. (12 flute)
3 in. (12 flute)
3 in. (12 flute)
3 in. (12 flute)

Diameter of End Mill

$5 / 16$ in. (4 flute)

$5 / 16$ in. (4 flute)

$5 / 16$ in. (4 flute)

$6 / 16$ in. (4 flute)

$5 / 16$ in. (4 flute)

$5 / 16$ in. (4 flute)

\begin{tabular}{cc} 
Diameter of End Mill \\
\hline 1 & $1 / 2$ in. (6 flute) \\
1 & $1 / 2$ in. (6 flute) \\
1 & $1 / 2$ in. (6 flute) \\
1 & $1 / 2$ in. (6 flute) \\
1 & $1 / 2$ in. (6 flute) \\
1 & $1 / 2$ in. (6 flute)
\end{tabular}

Diameter, nf Find Mill

$11 / 4$ in. (6 flute)

$11 / 4$ in. (6 flute)

$11 / 4$ in. (6 flute)

$11 / 4$ in. (6 flute)

$11 / 4$ in. (6 flute)

Speed(rpm)

6700

6700
6700

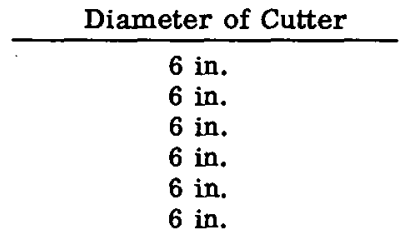

Finish

$(\mu$ in. $\mathrm{rms})$

40

70

125

45

70
125

Finish

35

60

110

30

60

125

\begin{tabular}{c} 
Finish \\
\hline 250 \\
140 \\
130 \\
120 \\
90 \\
90
\end{tabular}

Finish

35

60

110

50

70

100

Finish

40

60

90

40

40
110

110

\begin{tabular}{l} 
Finish \\
\hline 35 \\
70 \\
90 \\
35 \\
60 \\
110
\end{tabular}

$11 / 4$ in. (6 flute)

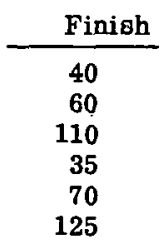

Diameter of Wheel

10 in. $x$ 60-Grain Crystolon 10 in. $\times$ 60-Grain Crystolon 10 in. $x$ 60-Grain Crystolon
Finish

11

18 
TABLE II

WEIGHT GAINS IN MG/DM ${ }^{2}$ OF ZIRCALOY-2 CORROSION TESTED FOR 14 DAYS IN $750^{\circ} \mathrm{F}$ STEAM

\begin{tabular}{ll} 
& Shaper \\
\hline Sharp Tool: & $\begin{array}{l}\text { Fine Feed } \\
\text { Medium Feed }\end{array}$ \\
& $\begin{array}{l}\text { Coarse Feed } \\
\text { Dull Tool: }\end{array}$ \\
& $\begin{array}{l}\text { Fine Feed } \\
\text { Medium Feed } \\
\text { Coarse Feed }\end{array}$
\end{tabular}

\begin{tabular}{c} 
No Pickle \\
\hline 25 \\
24 \\
24 \\
24 \\
24 \\
23
\end{tabular}

Pickled 1 Mil

Pickled 2 Mils

Slab Mill

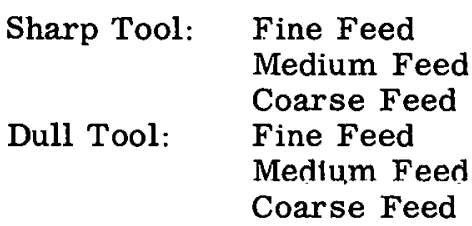
per Surface

Straddle Mill

\begin{tabular}{|c|c|}
\hline Sharp Tool: & $\begin{array}{l}\text { Fine Feed } \\
\text { Medium Feed } \\
\text { Coarse Feed }\end{array}$ \\
\hline Dull Tool: & $\begin{array}{l}\text { Fine Feed } \\
\text { Medium Feed } \\
\text { Coarse Feed }\end{array}$ \\
\hline
\end{tabular}

Shell Mill

$\begin{array}{ll}\text { Sharp Tool: } & \begin{array}{l}\text { Fine Feed } \\ \text { Medium Feed }\end{array} \\ & \text { Coarse Feed } \\ \text { Dull Tool: } & \text { Fine Feed } \\ & \text { Medium Feed } \\ & \text { Coarse Feed }\end{array}$

End Mili

(Overlap Facing)

\begin{tabular}{ll}
\hline Sharp Cutter: & Fine Feed \\
& Medium Feed \\
& Coarse Feed \\
Dull Cutter: & Fine Feed \\
& Medium Feed \\
& Coarse Feed
\end{tabular}

End Mill

(No Overlap Facing)

Sharp Cutter: Fine Feed Medium Feed Coarse Feed

Dull Cutter:

$$
\text { Fine Feed }
$$

Medium Feed

Coarse Feed

27
27
27
27
27
28

\begin{tabular}{c} 
per Surface \\
\hline 26 \\
27 \\
26 \\
26 \\
26 \\
28
\end{tabular}

$\begin{array}{lll}24 & 27 & 26 \\ 25 & 26 & 26 \\ 25 & 27 & 24 \\ 28 & 28 & 26 \\ 24 & 27 & 27 \\ 26 & 29 & 28\end{array}$

$\begin{array}{rrr}19 & 26 & 26 \\ 0 & 26 & 26 \\ 2 & 26 & 25 \\ 19 & 25 & 26 \\ 24 & 27 & 25 \\ 20 & 28 & 27\end{array}$

$\begin{array}{lll}25 & 27 & 27 \\ 23 & 27 & 27 \\ 24 & 28 & 27 \\ 24 & 28 & 28 \\ 24 & 28 & 26 \\ 25 & 28 & 27\end{array}$


TABLE II (Cont.)

WEIGHT GAINS IN MG/DM ${ }^{2}$ OF ZIRCALOY-2 CORROSION TESTED FOR 14 DAYS IN $750^{\circ} \mathrm{F}$ STEAM

\begin{tabular}{|c|c|c|}
\hline \multicolumn{2}{|c|}{$\begin{array}{c}\text { End Mill } \\
\text { (Edge Cut) }\end{array}$} & No Pickle \\
\hline Sharp Cutter: & $\begin{array}{l}\text { Fine Feed } \\
\text { Medium Feed } \\
\text { Coarse Feed }\end{array}$ & $\begin{array}{l}24 \\
24 \\
24\end{array}$ \\
\hline Dull Cutter: & $\begin{array}{l}\text { Fine Feed } \\
\text { Medium Feed } \\
\text { Coarse Feed }\end{array}$ & $\begin{array}{l}25 \\
24 \\
25\end{array}$ \\
\hline
\end{tabular}

Pickled 1 Mil

per Surface

Surface Grind

26
27
28
29
28
29

\section{6 \\ 27}

27
Pickled 2 Mils per Surface

TABLE III

WEIGHT GAINS IN MG/DM ${ }^{2}$ OF ZIRCALOY-2 CORROSION TESTED FOR 28 DAYS IN $680^{\circ} \mathrm{F}$ WATER

\begin{tabular}{ll} 
Shaper \\
\hline Sharp Tool: & $\begin{array}{l}\text { Fine Feed } \\
\text { Medium Feed } \\
\text { Coarse Feed }\end{array}$ \\
Dull Tool: & $\begin{array}{l}\text { Fine Feed } \\
\text { Medium Feed } \\
\text { Coarse Feed }\end{array}$
\end{tabular}

No Pickle

18

17

18

16

15

15
Pickled 1 Mil per Surface

22
22
22
19
21
22

Pickled 2 Mils per Surface

Slab Mill

\begin{tabular}{|c|c|}
\hline Sharp Tool: & $\begin{array}{l}\text { Fine Feed } \\
\text { Medium Feed } \\
\text { Coarse Feed }\end{array}$ \\
\hline Dull Tool: & $\begin{array}{l}\text { Fine Feed } \\
\text { Medium Feed } \\
\text { Coarse Feed }\end{array}$ \\
\hline
\end{tabular}

Straddle Mill

\begin{tabular}{ll}
\hline Sharp Tool: & Fine Feed \\
& Medium Feed \\
Dull Tool: & Foarse Feed \\
& $\begin{array}{l}\text { Fine Feed } \\
\text { Medium Feed } \\
\text { Coarse Feed }\end{array}$
\end{tabular}

Shell Mill

\begin{tabular}{ll}
\hline Sharp Tool: & Fine Feed \\
& Medium Feed \\
Coarse Feed \\
Dull Tool: & Fine Feed \\
& Medium Feed \\
& Coarse Feed
\end{tabular}

16

16

16

17

17

18

21

21

21

20

21

21

22

23

22

21

22

21 
TABLE III (Cont.)

WEIGHT GAINS IN MG/DM ${ }^{2}$ OF ZIRCALOY-2 CORROSION TESTED FOR 28 DAYS IN $680^{\circ} \mathrm{F}$ WATER

End Mill

\begin{tabular}{ll} 
(Overlap Facing) \\
\hline Sharp Cutter: & $\begin{array}{l}\text { Fine Feed } \\
\text { Medium Feed }\end{array}$ \\
Coarse Feed \\
Dull Cutter: & $\begin{array}{l}\text { Fine Feed } \\
\text { Medium Feed } \\
\text { Coarse Feed }\end{array}$
\end{tabular}

End Mill (No Overlap Facing)

\begin{tabular}{ll}
\hline Sharp Cutter: & $\begin{array}{l}\text { Fine Feed } \\
\text { Medium Feed } \\
\text { Coarse Feed }\end{array}$ \\
Dull Cutter: & $\begin{array}{l}\text { Fine Feed } \\
\text { Medium Feed } \\
\text { Coarse Feed }\end{array}$
\end{tabular}

End Mill

(Edge Cut)

$\begin{array}{ll}\text { Sharp Cutter: } & \begin{array}{l}\text { Fine Feed } \\ \text { Medium Feed } \\ \text { Coarse Feed }\end{array} \\ \text { Dull Cutter: } & \begin{array}{l}\text { Fine Feed } \\ \text { Medium Feed } \\ \text { Coarse Feed }\end{array}\end{array}$

\section{Surface Grind}

$\begin{array}{ll}\text { New Wheel: } & \text { Fine Feed } \\ & \text { Mcdium Fced } \\ & \text { Coarse Feed }\end{array}$

\section{DISCUSSION}

\section{A. Unpickled Machined Coupons}

Goldman (Ref 1) showed that unpickled Zircaloy-2 machined on a shaper is corrosion resistant in short-term tests in $680^{\circ} \mathrm{F}$ water. The enlarged scope of this experiment shows that all the surface treatments investigated produce corrosion resistant surfaces if the machining is properly performed. No real or significant differences in results for the various types of machining were noted even though cutting actions were different.

The effect of the sharpness or dullness of tools was significant, however. The peculiar behavior of the straddle-milled samples was traced directly

\begin{tabular}{c}
$\begin{array}{c}\text { Pickled } 1 \text { mil } \\
\text { per Surface }\end{array}$ \\
\hline 22 \\
22 \\
21 \\
22 \\
21 \\
22
\end{tabular}

\begin{tabular}{c}
$\begin{array}{c}\text { Pickled } 2 \text { mils } \\
\text { per Surface }\end{array}$ \\
\hline 22 \\
22 \\
21 \\
22 \\
22 \\
22
\end{tabular}

$\begin{array}{lll}8 & 22 & 22 \\ 8 & 21 & 21 \\ 7 . & 21 & 20 \\ 8 & 21 & 20 \\ 6 & 22 & 22 \\ 6 & 21 & 21\end{array}$

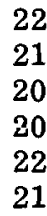

1 1

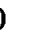

(1)




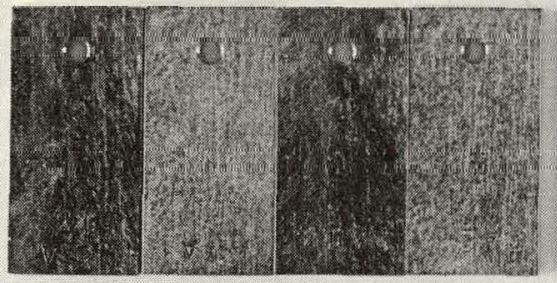

SHARP TOOL FINE FEED

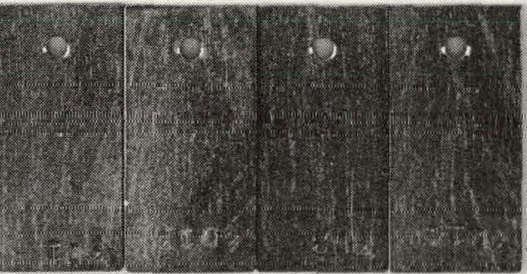

DULL TOOL FINE FEED

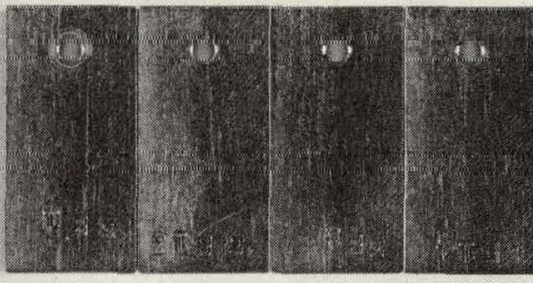

SHARP TOOL MEDIUM FEED

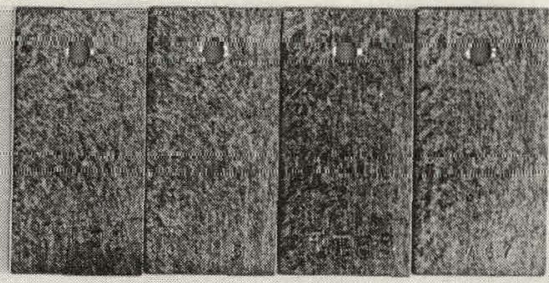

SHARP TOOL COARSE FEED

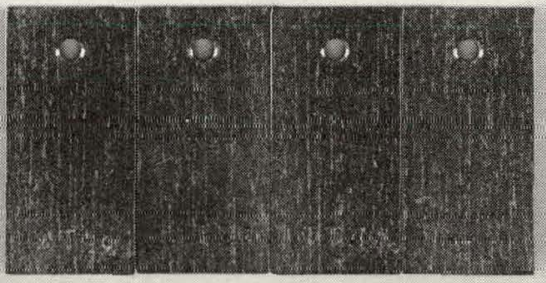

DULI TOOL MEDIUM FEED

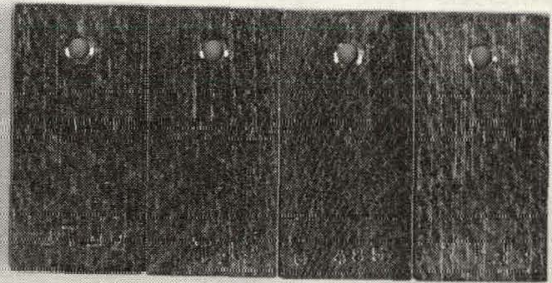

DULL TOOL COARSE FEED

Figure 1 As-Machined Zircaloy-2 Coupons Machined on a Horizontal Straddle Mill and Corrosion Testea for 14 Days in $750^{\circ}$ F Steam.

mill (shell mill) tool was comparable to that of the other coupons machined with sharp cutters.

The effect of surface grinding differed from previously reported results. The coupons in this experiment were black-gray and produced normal weight gains; coupons from earlier experiments were white and flaked within two weeks. The type of wheel and quantity of lubricant used are believed to be important factors in enhancing the corrosion resistance of these surfaces. Dry grinding with silicon carbide, and wet or dry grinding with alumina wheels produced distorted and burned surfaces. Although no direct data are available on the effect of grinding Zircaloy -2 with and without a lubricant, previous work on $18 / 8$ chrome nickel stainless steel revealed that dry grinding causes an oxide film and smeared metal surface (Ref 3). Wet grinding eliminates the temperature effect causing the oxide film and allows a clean cutting action rather than the smearing action mentioned.
Since zirconium is a "getter" and well known for its ability to absorb oxygen, it is reasonable to assume that dry grinding will cause the Zircaloy-2 surface to oxidize and will impair its corrosion resistance.* Apparently, a silicon carbide wheel with the lubricant flooding the workpiece is a necessary condition to prevent oxidation and optimize the grinding operation. In the current experiment, a water coolant was used; however, further experimental work is necessary to determine the effects of a mineral oil coolant.

No statistical difference was noted in the effects of the feeds on corrosion behavior.

\section{B. Pickled Machined Coupons}

No visual difference was noted between machined coupons pickled $1 \mathrm{mil}$ per surface and coupons

*L. S. Rubenstein, J.G. Goodwin, and F. L. Shubert, from work on the effect of oxygen on properties of Zircaloy-2, Bettis Laboratory, (October 1959). 
TABLE IV

CORROSION RESULTS FOR UNPICKLED ZIRCALOY-2 TESTED IN $750^{\circ} \mathrm{F}$ STEAM

Shaper

Sharp Tool

Dull Tool

Slab Mill

Sharp Tool

Dull Tool

Straddle Mill

Sharp Tool

Dull Tool

Shell Mill

Sharp Tool

Dull Tool

End Mill

(Overlap Face Cut)

Sharp Tool

Dull Tool

End Mill

(Non-overlap Face Cut)

Sharp Tool

Dull Tool

End Mill (Edge Cut)

Sharp Tool

Dull Tool

Surface Grind

New Wheel

Standards
Weight Changes in $\mathrm{mg} / \mathrm{dm}^{2}$ for the Following Days in Test

\begin{tabular}{|c|c|c|c|c|}
\hline 14 & 28 & 56 & 84 & 112 \\
\hline 24 & 29 & 45 & 59 & 76 \\
\hline 24 & 30 & 46 & 59 & 81 \\
\hline
\end{tabular}

25

51

63

67

87

85

94

26

32

53

23

42

34

55

45

69

55

21

25

25

29

30

63

59

78

68

93

52

76

24

24

30

52

64

80

95

29

50

62

78

92

27

30

53

49

63

63

79

93

33

78

91

24

30

52

52

64

80

82

95

65

96

27

34

52

67

82

97

29

36

61

83

105

134 


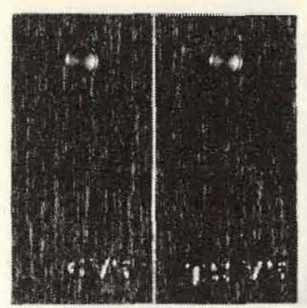

SHARP TOOL FINE FEED

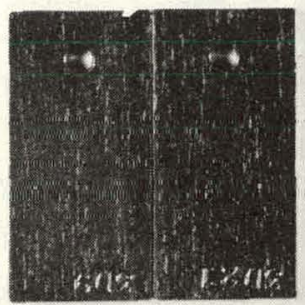

DULL TOOL FINE FEED

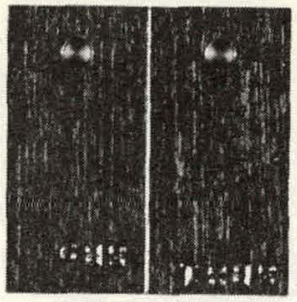

SHARP TOOL MEDIUM FEED

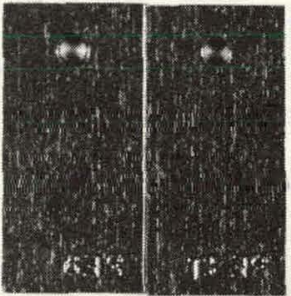

DULL TOOL MEDIUM FEED

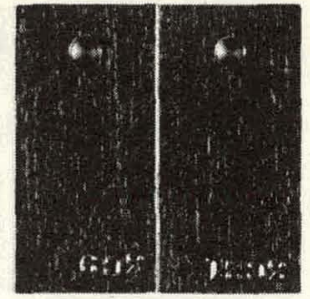

SHARP TOOL COARSE FEED

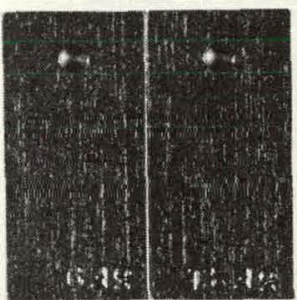

DUIL TOOL COARSE FEED

Figure 2 Zircaloy-2 Coupons Machined on a Horizontal Straddle Mill and Pickled 0.002 Inch per Surface. Coupons Shown after Corrosion Test in $750^{\circ} \mathrm{F}$ Steam for 140 Days.

pickled 2 mils per surface. The pickling operation removed the adverse effect of the defective tool on the straddle-milled samples as well as any effect of the dull shell-mill cutter.

The effects of pickling depth on weight gain were uncertain in both $680^{\circ} \mathrm{F}$ water and $750^{\circ} \mathrm{F}$ steam. An examination of weight gains of the standard Zircaloy-2 coupons placed in each autoclave indicated that at least part of the difference in results was caused by the autoclaves. Based on the statistical analysis of this particular study (Appendix I), no definite comparisons can be made as to which depth of pickling gave hetter results. Figures 3 through 6 show comparisons among the different treatments.

\section{CONCLUSIONS}

Machined, unpickled Zircaloy-2 exhibits good corrosion resistance if properly machined. The sharpness and hardness of the tools used had a definite effect on the corrosion resistance of machined, unpickled Zircaloy-2. Variations in the feed and type of machine used had no effect on the corrosion behavior when a sharp cutter was used. Surface grinding with a silicon carbide wheel and ample lubricant does not adversely affect the corrosion resistance of Zircaloy-2. Corrosion behavior differed more as a result of the difference in the autoclaves used for testing than as a result of the difference between coupons pickled 1 and 2 mils per surface.

\section{APPENDIX I: STATISTICAL ANALYSIS*}

An experimental design for the present study included a complete factorial design for each test condition $\left(680^{\circ} \mathrm{F}\right.$ water and $750^{\circ} \mathrm{F}$ steam) and involved seven machines, three feeds, sharp and

*W. L. Davis, Bettis Laboratory, now with the Atlantic Refining Company, Philadelphia, Pa. 
TABLE V

CORROSION RESULTS FOR ZIRCALOY-2 PICKLED 1 MIL/SURFACE AND TESTED IN $750^{\circ} \mathrm{F}$ STEAM

Weight Changes in $\mathrm{mg} / \mathrm{dm}^{2}$ for the Following Days in Test

$\begin{array}{llllll}14 & \underline{28} & \underline{5} & \underline{84} & \underline{112} & \underline{140}\end{array}$

Sharper

Sharp Tool

Dull Tool

$27 \quad 35$

60

76

93

105

27

35

60

78

96

107

Slab Mill

Sharp Tool

Dull Tool

58

57

74

92

103

28

75

91

101

Slradule Mill

Sharp Tool

Dull Tool

Shell IVill

Sharp Tool

Dull Tool

End Mill

(Overlap Face Cut)

Sharp Tool

Dull Tool

27

26

33

35

57

58

72

75

89

92

101

27

26
27

34

34

59

57

74

78

91

94

102

108

32

34

58

59

76

93

104

\section{b8}

60

16

79

91

102

Dull Tool

End Mill (Edge Cut)

Sharp Tool

Surface Grind

New Wheel

28

35

59

75

92

101

Standards

26

42

68

99

124

151 
TABLE VI

CORROSION RESULTS FOR ZIRCALOY-2 PICKLED 2 MILS/SURFACE AND TESTED IN $750^{\circ} \mathrm{F}$ STEAM

Weight Changes in $\mathrm{mg} / \mathrm{dm}^{2}$ for the Following Days in Test

Shaper

Sharp Tool

Dull Tool

Slab Mill

Sharp Tool

Dull Tool

Straddle Mill

Sharp Tool

Dull Tool

Shell Mill

Sharp Tool

Dull Tool

End Mill

(Overlap Face Cut)

Sharp Tool

Dull Tool

End Mill

(Non-overlap Face Cut)

\section{Sharp Tool}

Dull Tool

End Mill (Edge Cut)

Sharp Tool

Dull Tool

Surface Grind

New Wheel

Standards

$\underline{28}$

$\underline{56}$

33

34

25

27

34

34

52

53

84

$\underline{112}$

140

26
27

53

55

67

69

84

88

108

113

26

22

34

34

52

55

65

69

80

87

107

27

26

33

33

52

56

65

71

82

90

107

117

51

54

64

79

103

66

84

109

86

27

วง

34

51

53

03

66

78

104

106

28

36

54

66

79

105

26

42

60

78

98

131 
TABLE VII

CORROSION RESULTS FOR UNPICKLED ZIRCALOY-2 TESTED IN $680^{\circ} \mathrm{F}$ WATER

Weight Changes in $\mathrm{mg} / \mathrm{dm}^{2}$ for the Following Days in Test

Shaper

Sharp Tool

Dull Tool

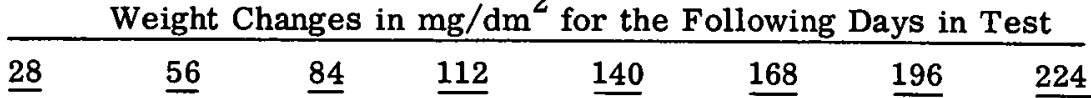

Slab Mill

Sharp Tool

Dull Tool

\title{
40
}

$44 \quad 50$

Straddle Mill

Sharp Tool

$-1$

2
15

2
21

2
25

14

30

5
35

8
39

11

Shell Mill

Sharp Tool

End Mill

(Overlap Face Cut)

Sharp Tool

Dull Tool

\section{End Mill}

(Non-overlap Face Cut)

Sharp Tool

Dull Tool

End Mill (Edge Cut)

\section{Sharp Tool \\ Dull Tool}

Surface Grind
16

16

25

26

27

28

52

58

23

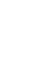

$21 \quad 27$

36
28

43
35

49

55

62

$41 \quad 45 \quad 51$

18

17

24

22

17

17

23

23

28

29

39

46

45

46

52

44

59

49

67

57

New Wheel

16

22

27

33

42

49

53

58

Standards
21

26
38

48

56

62

74 
TABLE VIII

CORROSION RESULTS OF ZIRCALOY-2 PICKLED 1 MII/SURFACE AND TESTED IN $680^{\circ} \mathrm{F}$ WATER

Weight Changes in $\mathrm{mg} / \mathrm{dm}^{2}$ for the Following Days in Test

\begin{tabular}{lllllll}
\hline 28 & $\underline{56}$ & $\underline{84}$ & $\underline{112}$ & $\underline{140}$ & $\underline{168}$ & $\underline{196}$
\end{tabular}

Shaper

Sharp Tool

$22 \quad 26$

21

26

29

33

Dull Tool

$25 \quad 28$

32

41

48

$41 \quad 47$

54

Slab Mill

Sharp Tool

Dull Tool

$21^{-} \quad 25 \quad 28$

$\begin{array}{lll}21 & 25 & 28\end{array}$

28
28

31

31

36

38

42

44

48

Straddle Mill

Sharp Tool

Dull Tool

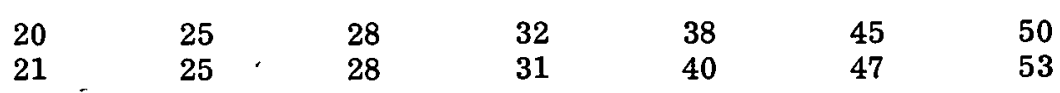

Shell Mill

Sharp Tool

Dull Tool

21

26

28

28

30

32

37

46

47

53

$21-25-28-2$

39

53

End Mill

(Overlap Face Cut)

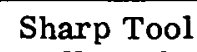

22

Dull Tool

22

End Mill

(Non-overlap Face Cut)

Sharp Tool

Dull Tool

21

21

25

26

28

28

32

32

38

42

46

48

52

54

End Mill (Edge Cut)

Mharp Tưol

Dull Tool

32

32

38

39

45

47

52

Surface Grind

New Wheel

22

26

29

32

37

45

50

Standards

22

27

30

42

51

57

63 
TABLE IX

CORROSION RESULTS OF ZIRCALOY-2 PICKLED 2 MILS/SURFACE AND TESTED IN $680^{\circ} \mathrm{F}$ WATER

Weight Changes in $\mathrm{mg} / \mathrm{dm}^{2}$ for the Following Days in Test

$\begin{array}{lllllll}\underline{28} & \underline{56} & \underline{84} & \underline{112} & \underline{140} & \underline{168} & \underline{196}\end{array}$

Shaper

Sharp Tool

$23 \quad 27$

21

27

31

30

34

46

53

53

57

Dull Tool

Slab Mill

Sharp Tool

Dull Tool

21

21

25

25

43

51

55

Straddle Mill

Sharp Tool

Dull 'Tool

21

21

26

25

29

28

34

33

47

46

52

52

56

56

Shell Mill

Sharp Tool

Dull Tool

21

26

25

28

33

33

46

47

53

53

56

21

29

$22 \quad 26$

30

31

32

34

44
48

51

51

56

Dull Tool

End Mill

(Jon-overlap Face Cut)

Sharp Tool

Dull Tóol

21

21

25

26

30

33

39

45

46

53

56

$30 \quad 39$

63

56

End Mill (Edge Cut)

Sharp Tool

Dull Tool

22

26

31

33

45

45

53

53

56

30

34

45

$+2$

$\frac{\text { Surface Grind }}{\text { New Wheel }}$

22

26

30

34

43

52

56

$\underline{\text { Standards }}$

22

29

34

50

55

63

72 


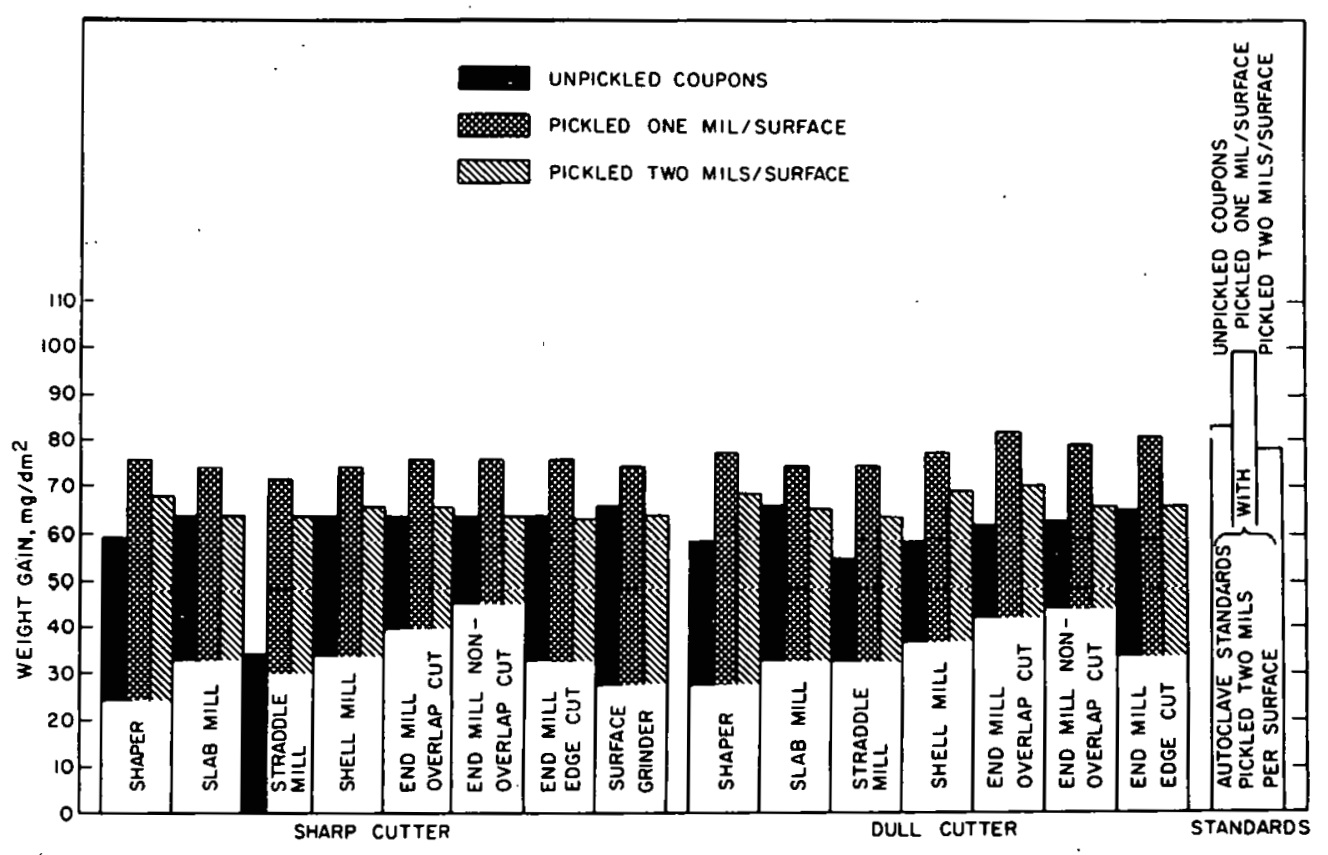

Figure 3 Average Weight Gains for Machined Coupons affer 84 Days in $750^{\circ} \mathrm{F}$ Steam.

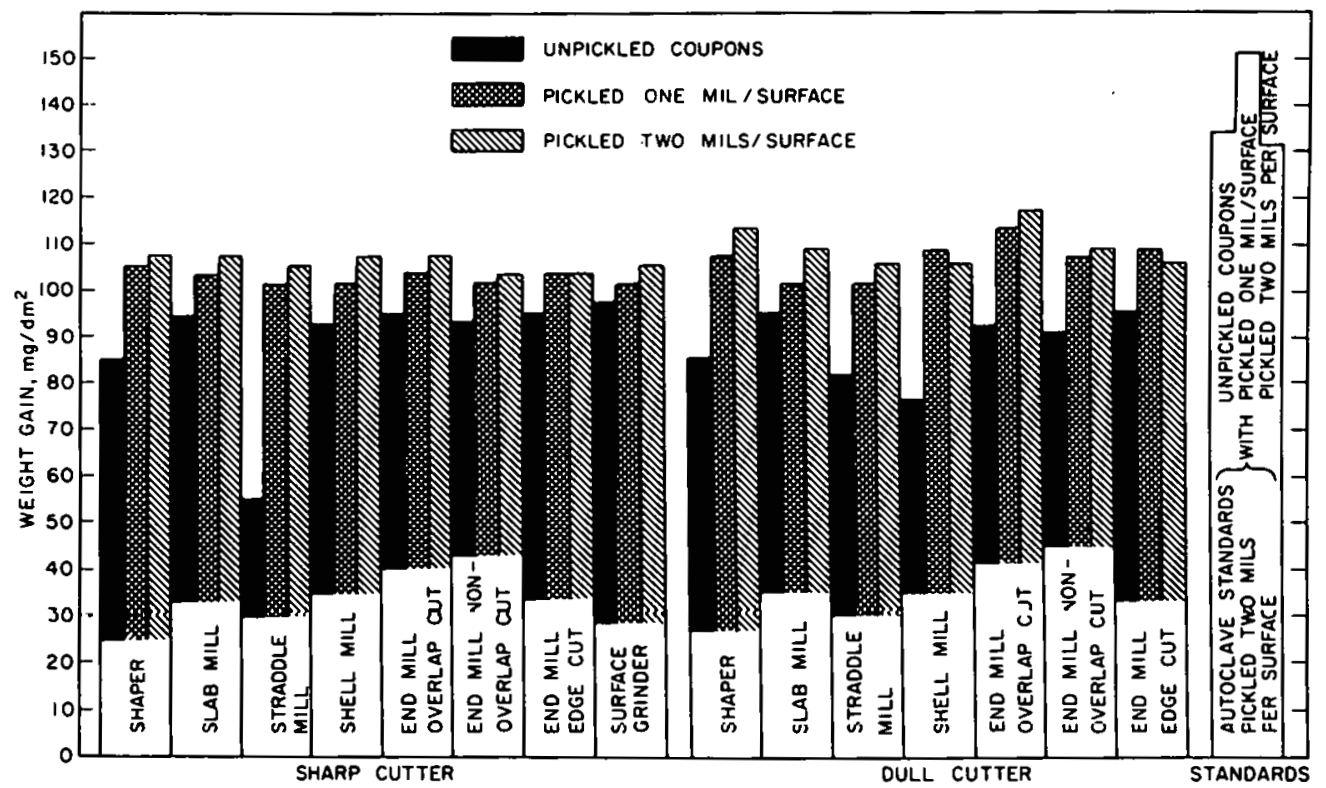

Figure 4 Average Weight Gains for Machined Coupons after 140 Days in $750^{\circ} \mathrm{F}$ Steam.

dull cutters, three pickling depths, two autoclaves, and two replications.

Delays in coupon preparation necessitated the placement of coupons with different pickling depths in different autoclaves. Two standard Zircaloy-2 specimens were placed in each autoclave; with this information, it was possible to derive a statistic for testing the effect of pickling depth after adjusting for differences between autoclaves. However, this statistic was relatively inadequate because of limited information. Because of financial 


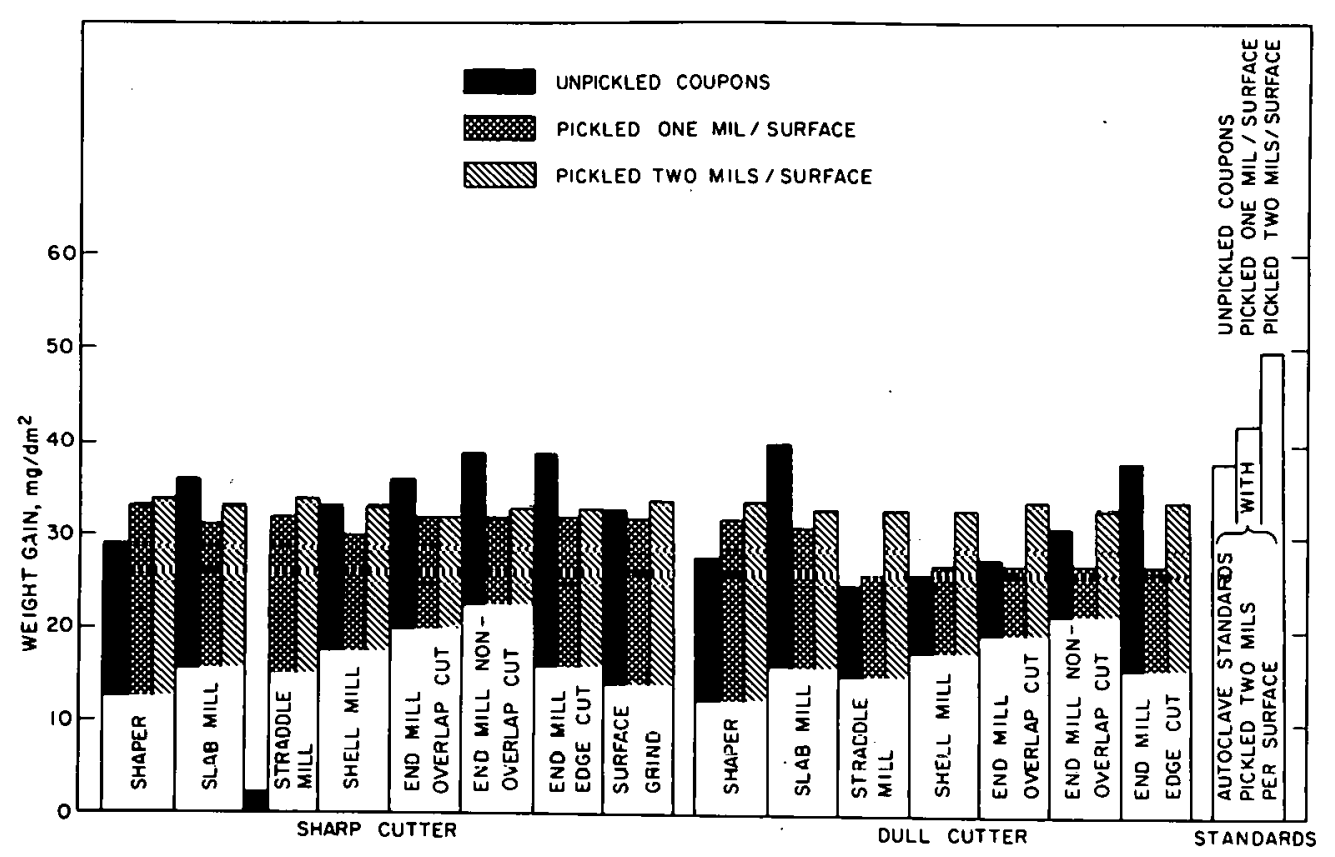

Figure 5 Average Weight Gains for Machined Coupons after 112 Days in $680^{\circ} \mathrm{F}$ Water.

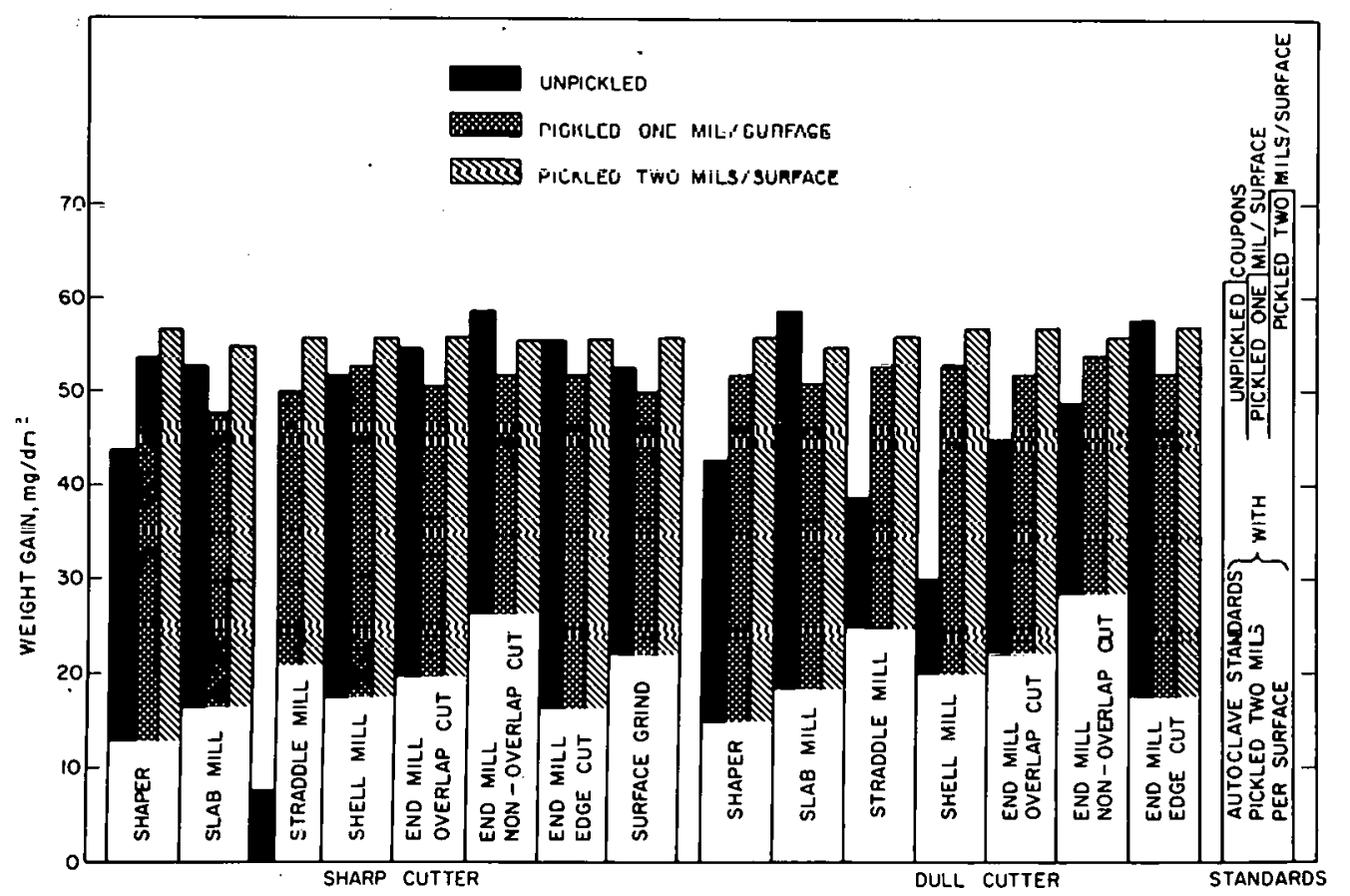

Figure 6 Average Weight Gains for Machined Coupons after 196 Days in $680^{\circ} \mathrm{F}$ Water. 
limitations, one autoclave was eliminated after 28 days of testing for all but the unpickled specimens.

\section{A. Method of Analysis}

The results caused by the difference in the autoclaves interacted with the other experimental results. This was verified by tests of significance. As a consequence, whenever applicable, all interactions involving the autoclaves were pooled with duplicate measurements for testing the significance of the remaining factors. All conclusions were based on a probability level of 0.95 .

\section{B. Conclusions}

The variability attributable to the different autoclaves was high; as a result the magnitude of some of the other effects reported as significant may have been too small to be of practical importance. This was particularly true for the machined coupons tested in $680^{\circ} \mathrm{F}$ water.

The over-all effects of pickling depth and machine feeds were judged too small to be considered as other than random variations. Some particular combinations of variables were important for the unpickled specimens but were not large enough to be considered important for the pickled specimens.

The straddle-milled, unpickled coupons showed lower weight gains than the unpickled coupons processed by the other machines. However, this effect was not noticed for the pickled specimens.
The coupons processed by the dull cutter on the shell mill showed erratic corrosion resistance in both the steam and water tests.

The unpickled specimens machined with a dull tool showed higher initial weight gains as well as a higher rate of gain than those machined with a sharp tool.

The pickled coupons machined with a dull tool showed higher weight gains than those machined with a sharp tool, but the rate of gain was the same for both groups.

\section{ACKNOWLEDGMENTS}

The author thanks J. Maringo of the Development Machine Shop for his aid in preparation of the coupons, the Corrosion Test Laboratories of the Engineering Laboratories for the corrosion tests; A. C. Nelson and W. L. Davis for their help in statistically analyzing the data; and S. Kass for his guidance in performing and reporting the experiments.

\section{REFERENCES}

1. K. M. Goldman, "Report of the March 1953 Meeting of the Zirconium Alloy Corrosion Committee," WAPD-MM-200 (Del.) (1953).

2. S. Kass, D. J. Fontanese, A. E. Oaks, and D. B. Scott, "Pickling of the Zircaloys prior to Corrosion Exposure," WAPD-TM-141 (1958).

3. K. G. Lewis, "Surface Finish," Metal Treatment and Drop Forging, Vol 25 (1958), pp 377-384. 